Илијана Р. Чутура

Универзитет у Крагујевцу

Педагошки факултет у Јагодини

Катедра за филолошке науке

\title{
МЕЂУОДНОС ВРЕМЕНА И УЗРОКА У АНДРИЋЕВИМ РОМАНИМА
}

Предмет рада јесу карактеристичне јединице са временским значењем у романима На Дрини ћуприја и Травничка хроника. Ове јединице анализирамо са два аспекта. Први је њихова функција у наративном ткиву романа, пре свега исказивање протока времена и својеврсних „прескока" између значајних периода или догађања. Други аспект јесте семантички. У том смислу, у раду ће се извршити класификација и анализа карактеристичних темпоралних одредби. Посебна пажња посвећује се, на оба плана анализе, међуодносу времена и узрока с обзиром на то да се, на мотивском плану романа, истичу паралеле протицања времена и различитих типова временске локализације са функцијама блиским пасивном узроку, изазивачу или омогућивачу.

Кључне речи: време, темпорална локализација, време приповедања, узрок, пасивни узрок.

* ilijana.cutura@gmail.com

* Рад је настао у оквиру пројекта 178014 Динамика структура савременог српског језика, који финансира Министарство просвете и науке Републике Србије. 


\section{1. Уводне напомене}

Предмет рада јесте међуоднос категорија времена и узрока у Андрићевим романима На Дрини ћуприја и Травничка хроника. Тај међуоднос пре свега посматрамо са аспекта семантичких, а не граматичких структура, али и као филозофску и поетску доминанту дела.

У анализираним Андрићевим романима време има посебну - готово главну - улогу узрочника свих ствари и промена. Како Первић наводи, „[а]ко није езотерик, Андрић није ни егзотерик; због тога што зна за каузалитет,'случај' и парадокс нису за њега неприродне појаве. Свет није ни хаос, ни фаталност, ни кошмар, ни игра, иако на све то личи. Све што се догађа има за Андрића свој узрок и ефекат, разлог и логику, али је тешкоћа у томе да се ови издвоје из 'објективног узајамног дејства у коме се налазе"' (Первић 1962: 217-218).

1.1. Међуоднос времена и узрока представља једну од основних релација на којима се темељи сама категорија каузалности с обзиром на то да су однос временске антериорности узрока према последици и однос временске симултаности узрока и последице нужни за успостављање каузалне везе (в. Ковачевић 2012: 33-40). Природно је, стога, постојање субпоља узрочно-временске интерференције где одређени типови граматичких јединица, примарно временски, у одређеном контексту добијају „узрочно осложњавање”. Ковачевић издваја такве предлошко-падежне моделе и типове клауза, наглашавајући: „Међутим, прије него што контекст елиминише или у други план потисне временско значење, наглашавајући узрочно, - нужно мора претходити стање временско-узрочне семантичке 'сливености"' (Ковачевић 2012: 176). Први тип таквих модела јесу предлошко-падежне конструкције и синтагме: $n p u / y+$ локатив, н $a+$ акузатив, код 
+ генитив, $n p u+$ локатив, $\varnothing+$ инструментал, $c a+$ инструментал, након/после + генитив. Друго, временско значење глаголских прилога може се комбиновати са узрочним „у контекстима који подразумијевају да се суоднос садржаја глаголског прилога (односно чешће његове синтагме) и садржаја предиката (односно његове синтагме) може схватити и као однос узрока и посљедице” (Ковачевић 2012: 178). Трећи граматички модел чине сложене реченице с временским везником у којима је временски однос између управне и зависне клаузе граматикализован, али међу њима постоји и имплицитни, смисаони узрочни однос.

Показује се, међутим, да Андрић у романима Травничка хроника и На Дрини ћуприја веома често имплицитно исказује преплитање категорија времена и узрока, користећи адвербативе са значењем временске локализације и дајући времену тек на ширем, идејном и филозофском плану, функцију „скривене узрочности” (в. Свонсон 2012), додатно делујућег фактора или омогућивача.

\section{2. Семантичко осложњавање временских одредби узрочним значењем у Андрићевим романима}

Избор романа које анализирамо у овом раду предодређен је чињеницом да време у њима има посебан статус, почев и од самог наслова Травничке хронике. Одређена референцијална локализација у оба романа углавном се остварује конструкцијама крајем/почетком $x$ века/ године, мада су заступљени и други модели. Међу њима је помало неуобичајена конструкција „(године) из средине $x$ века", репрезентована издвојеном групом примера: ${ }^{3}$

3 Ознаком TX у раду се упућује на роман Травничка хроника, а ознаком НДЋ на роман На Дрини ћуприја. 
У то време, крајем XVII века, по Босни се певало, говорило и шапутало много о Мађарској, коју је турска војска, после столетне окупације, стала да напушта. (НДЋ, 82); Тако су, тих првих година XIX века, мислили и желели у себи угледни Травничани, али разуме се да је то и остало у њима, јер код сваког Травничанина има од жеље до помисли па до њиховог видног или гласног израза дуг и кривудав пут који се лако не прелази. А догађаја и промена било је у последњим временима - то јест крајем XVIII и почетком XIX века - заиста много и од сваке руке. (TX, 18); Кад су са почетком 1812. године стали да се све чешће указују знаци и јављају гласови о могућности новог рата, Давила је при сваком од тих гласова обузимала лака и неприметна несвестица као човека који види да га чекају познате муке на које су га досад више пута ударали. (ТХ, 409);

За тих двадесет и пет година из средине XIX века два пута је у Сарајеву морила куга и једном колера. (НДЋ, 116); То су биле оне неколике десетине година из средине деветнаестог века за којих је Турска Царевина догоревала у тихој грозници (НДЋ, 110).

2.1. Одређени типови временске локализације имају изразито важну функцију на композиционом плану оба романа. Њима се „прескачу” временски периоди у којима збивања задржавају исти смер, односно у којима нема великих и за ткиво текста значајних догађања. На самом завршетку XVIII главе романа Травничка хроника наглашава се суштина овог поступка:

Тако је текао живот вароши и конзулата, од лета до јесени и од зиме до пролећа, без догађаја и других промена до оних које доноси свагдашњи живот и ход годишњих доба по себи. А хроника срећних и мирних година је кратка. (TX, 385)

Природно је што у романима овога типа, блиским историјском наративу који не може структурирати 
„причу као јединствену, кохерентну и у себи затворену цјелину” (Лешић 2010: 376), приповедање има фрагментарни карактер. Ово је посебно уочљиво у роману $\mathrm{Ha}$ Дрини ћуприја који, са својим „обликом древног летописа" (Кољевић 1982: 61), има композициони склоп сачињен од низа самосталних епизода које су и саме по себи изграђене око неколико мотива (Милошевић 1976: 18). ${ }^{4}$ Стога су карактеристични специфични „прескоци времена”, нарочито на почетку глава романа, као у примерима са глаголима проћu/пролазити:

Пролазиле су године, смењивала се лета и јесени, зиме и пролећа, одлазили су и враћали се радници и мајстори. Сада је сва Дрина била пресвођена, али не мостом него дрвеним скелама које су личиле на бесмислен и замршен сплет борових греда и дасака. (НДЋ, 70); Прошла је прва стотина година, време дуго и смртоносно за људе и многа њихова дела, али неосетно за велике грађевине, добро смишљене и тврдо засноване, а мост са капијом и караван-серај поред њега стајали су и служили као и првог дана. (НДЋ, 82, почетак V главе); Пролазили су месеци и година се ближила крају а аустријски конзул, за кога се раније веровало да ће стићи у стопу за француским конзулом, није долазио. Свет поче и да заборавља на ту могућност. (TX, 107, почетак V главе)

4 Делић (2011: 122) износи претпоставку да је и Андрићев стваралачки поступак био сличне природе: „Врло је вјероватно да је Андрић поједина поглавља својих романа писао не оним редом како су поређана у књизи, већ како су се наметала писцу. Као што зидар клеше и припрема појединачне камене блокове прије него што их угради у грађевину, прилике су тако и да је наш писац припремао појединачна поглавља, па их накнадно 'уланчавао', односно 'поступком низања' уграђивао у роман. Тако поједина поглавља, нарочито у роману На Дрини ћуприја, имају своју релативну самосталност и замисливи су и као посебне приповијетке”. 
Слично као у наведеним примерима, у романима се јављају и други експлицитни искази којима Андрић опонира историјско и „људско” време, истичући њихову несамерљивост која, на крају, у поступку компоновања романа доводи до испуштања „нерелевантних” година и деценија без значајнијих прича и догађаја:

Гледајући све то, из дана у дан, из године у годину, наш свет је почео да губи рачун о времену и стварним намерама градитеља. (НДЋ, 69); Пролазило је време над мостом и касабом, у годинама, у деценијама. То су биле оне неколике десетине година из средине деветнаестог века за којих је Турска Царевина догоревала у тихој грозници. Мерене оком савременика, те су године изгледале сразмерно мирне и срећне... (НДЋ, 110, почетак 7. главе).

2.2. Истакнут и веома фреквентан израз којим Андрић можда и најекономичније сажима време јесте израз с временом. У структури овог предлошко-именичког прилошког израза носилац категоријалне семантике је једина пунозначна лексема (именица време). Међутим, показује се да је време у овом изразу или довољан узрок одређених промена или омогућивач трајног деловања одређеног узрочника, те израз има значење пасивног, нужно и непрестано делујућег узрока. ${ }^{5}$ Фреквентност овог израза у анализираним романима може се тумачити самим односом времена приповеданог и времена приповедань које је морало бити компримовано (Принс 2011, под време), али и структуром фабуле с обзиром на то да

5 „Дакле, израз има 'пасивно узрочно' значење као једну од латентних и секундарних компонената. Секундарна је значењска компонента омогућивача и она зависи, опет, од семантике целог исказа и природе примарног узрока" (Чутура, Јовановић 2008: 130). Овај семантички елемент може се тумачити и као својеврсни остатак некада продуктивних инструменталних модела са значењем узрока, посебно омогућивача (в. Ивић 2005). 
„фабула често подразумијева не само збивања у хронолошком низу већ и развој догађаја. А то у њихов редослијед уноси каузалитет као конструктивни принцип вишега реда" (Лешић 2010: 403).

Проток времена је неминовна и иреверзибилна појава која сама собом доноси измене и појачава њихов интензитет, те се може говорити и о значењском елементу реципроцитета (в. Ковачевић 2003) ${ }^{6}$ којем се придодаје и компонента начина с обзиром на то да промена која се дешава $c$ временом подразумева изложеност узроку у дужем временском периоду, а самим тим и постепеност промене (Чутура, Јовановић 2008: 130). У овој категорији време игра улогу блиску узроку-ефектору. ${ }^{7}$

Изразом назначен проток времена (који има карактеристике развојног времена) кореспондира са променама различитих типова. Најчешће, време се појављује као омогућивач деловања примарног узрока, али и као једини фактор који доводи до промена. Људи и грађевине с временом или с годинама старе и пропадају или, пак, постају лепши, стаситији и чвршћи (као што и мост постаје бељи и стабилнији) те проток времена има снагу

6 Ковачевић (2003: 119) истиче да „у српском језику нема ниједне падежне нити приједлошко-падежне форме којом би се примарно изражавало пропорционално значење. Међутим, у неким полисемичним падежним и приједлошко-падежним конструкцијама у строго одређеним контекстима који подразумијевају семантички однос двају компаратива може се као примарно синтагматско значење изразити и значење пропорционалности". Као једну од таквих форми Ковачевић наводи са+инструментал и пример: „С већом старости веће је и искуство”. За разлику од пропорционалних, конструкција с временом на плану израза искључује компаратив али га на неки начин подразумева с обзиром на једносмерност (иреверзибилност) временског тока и поступност промене (в. Чутура, Јовановић 2008: 133).

7 „Као агенс не-лице, узрок типа ефектор у датим околностима 'аутоматски', сам по себи доводи до посљедице несвјесног, спонтаног, реакцијског типа." (Ковачевић 2012: 50) 
довољног пасивног узрока. ${ }^{8}$ Наведена значења потврђујемо следећим примерима:

Све се у овој земљи с временом окретало у изненађење и све је, у сваком тренутку, могло постати противно од онога што изгледа. (ТХ, 231); Та буна у Србији задавала је с временом све више бриге и незгоде, штете, трошкова и губитака целој турској Босни па и Травнику... (ТХ, 19); Откако је царевине било је и тога, јер нема власти без буне и завере, као што нема имања без бриге и штете. Али с временом је буна у Србији почела да задире све више у живот целог босанског пашалука, а нарочито у живот ове касабе која је на сат хода од границе. (НДТ, 95); Њихов град, то је у ствари једна тесна и дубока раселина коју су нараштаји с временом изградили и обрадили, један утврђен пролаз у ком су се људи задржали да живе стално, прилагођавајући кроз столећа себе њему и њега себи. (ТХ, 15); Шта је било даље од тога

8 Поред израза $c$ временом Андрић за исказивање овог значења употребљава и изразе $c(a)$ годинама, кроз столећа/векове и зависне реченице типа „како су пролазиле године // како је протицало време”. Оваква улога времена није карактеристична само за анализиране романе. Тако, на пример, Питулић (2012: 258) у вези са Аникиним временима примећује: „У такав амбијент писац смешта и попа Вујадина, а између њега и парохијана поставља међу, отклон или некакву неразјашњиву, готово демонску силу која нарушава устаљену хармонију. Андрић то назива 'нека нелагодност' која је 'с временом све више расла". Заступљеност израза овог значења у Аникиним временима илуструјемо и следећим примерима: „Међутим, с годинама, трговина је скренула на другу страну и напустила вишеградски друм” (56); „С годинама је све више пио, али увек са мером и укусом” (56); „Он је у току година, у сталном додиру са људским злом и људском муком, стекао своје нарочито искуство, према коме је и несвесно удешавао своје поступке" (59); И Михаило је удисао дим и ваздух, вишеградски ваздух, гледао куће и оштре врхове брда и пропланке за које су се, с годинама, везале његове мисли; уз сталан планински облик стална мисао. (84). 
дечака у сепету то казују све историје на свим језицима, и то се боље зна у широком свету него овде код нас. $C$ временом он је постао млад и храбар силахдар на султановом двору, па капудан-паша, па царски зет, војсковођа и државник светскога гласа, Мехмед-паша Соколи, који је на три континента водио већином победоносне ратове, проширио границе Турске Царевине, осигурао је споља, и добром управом учврстио изнутра. (НДЋ, 26); Али сада, када се после толико месеци ишчекивања та претња заиста остварила, то га је забринуло мање него што се могло очекивати. Јер, с временом, он се био измирио са том могућношћу. (ТХ, 107); С временом, живећи и радећи са Ибрахим-пашом, Давил ће се навикнути на њега, стварно спријатељити са њим и увидети да се испод необичног изгледа крије човек који није ни без срца ни без памети, који је трајно и потпуно унесрећен, али који није неприступачан свима бољим осећањима које његова раса и његова каста познају и допуштају. (ТХ, 198); Давна, који сада више није имао слободан приступ у Конак као у време Мехмед-пашино, јер је потпуно прешао у службу француског конзула, пронашао је ипак с временом везе и путеве да о свему буде обавештен, о везиру, о главним личностима, о односима између њих и о начину на који се свршавају важни послови. (ТХ, 199); С временом он је постао неопходан у канцеларијама друштва, код доласка бродова, у општењу са странцима. (ТХ, 134).

Сличну назнаку прогресије која се догађа по закономерности протока времена Андрић остварује и изразом с годинама, на пример:

Укратко, да живе у средини која човека са Запада најпре растроши, затим га учини болесно раздражљивим и тешким себи и другима, да га најпосле, с годинама, потпуно измени, савије и много пре смрти сахрани у глувој равнодушности. (ТХ, 18); Као што често бива код те врсте жена, с годинама су се јављале нове настраности. (ТХ, 126). 
Проток времена јавља се и као омогућивач промена које утемељују искуства, ставове и навике људи и њихову филозофију која је и сама неретко везана за време, пролазност онога што ремети устаљене магистралне линије постојања и сталност самих тих магистрала. Тако, сам крај пете главе романа На Дрини ћуприја заокружује и сумира становиште да је време нужан услов за формирање егзистенцијалне филозофије колектива. Причу о великим поводюима Андрић поентира тиме да је „нараштај за нараштајем учио да не жали преко мере оно што мутна вода однесе”, слично као и у наредном делу текста, где се експлицира да су формирања колективних ставова резултат утицаја времена:

Али време је вршило свој утищај и нови нараштаји су се $c$ временом навикли и измирили с тим да својим ноћним осећањима пуштају маха при слабој светлости општинског фењера, а да се не бацају сваки пут на њега каменом, штапом или првим предметом који им дође до руке. (НДЋ, 170)

2.3. У анализираним романима Андрић неретко истиче да историјски периоди, крупна дешавања, социјалне парадигме везане за дужи временски период и одређено подручје детерминишу и живот појединаца и односе међу њима. Квалитативно одређени временски периоди са својим историјским и социјалним карактеристикама стоје као нека врста латентног узрочника у ланцу који доводи до одређених (ре)акција индивидуе. У том смислу, говорећи о односу индивидуализације и тотализације механизама моћи, Брајовић о роману Травничка хроника каже: „У првом реду окренута тематизацији далеких одјека тзв. високе, државне политике као својеврсних дипломатских 'бура у чаши воде' на балканској маргини европског континента, те бивајући, према томе, модерна углавном у свом 'панорамски' сни- 
жавајућем иронијском третману одабране тематике, Андрићева уметничка реконструкција 'конзулских времена' у доба Наполеонових похода својим историјским замахом готово да, наиме, и не дотиче онај други, битно модернистички аспект индивидуализације и тотализације моћи као управљачких прерогатива волунтаристичке сингуларности наспрам такорећи деперсонализоване плуралности оних којима се управља" (Брајовић 2011: 70). Управо је можда најбољи пример за ову поткатегорију релација времена и узрока однос између Давила и Дефосеа у роману Травничка хроника:

Давил је одмах помислио да пред собом има право дете нових времена, новог париског младића, смелог и сигурног у говору и покретима, безбрижног, блиског стварности, увереног у своју снагу и своје знање и склоног да и једно и друго прецењује. (ТX, 70); Та разлика у годинама не би била велика ствар у другим временима и друкчијим приликама. Али бурна времена, са великим променама и социјалним поремећајима, ископају и продубе непремостив јаз између два нараштаја и створе од њих стварно два света. (ТX, 71); Та безобзирност „новог покољења” час би наљутила а час растужила конзула. (ТХ, 98)

Њихове разлике у мишљењу и понашању имају значајно место у роману и објашњавају се тиме што су двојица Француза сазревала у различитим приликама, што је сваки од њих формирао сопствени идентитет - a тиме и обликовао поглед на нову средину - у специфичним друштвеним и политичким околностима (в. Марковић 2013). Ово није усамљен пример експлицирања „друкчијих времена”, што се, између осталог, огледа и у Андрићевим синтагмама типа „придев или заменица + именица време у плуралу” (Аникина времена, конзулска времена, нова времена): 
И тако су отпочела нова времена под окупацијом коју је свет, не могући је спречити, сматрао у души привременом. (НДТ, 161); У тим временима важност моста као једине сигурне везе између босанског пашалука и Србије необично је порасла. (НДЋ, 98); Чим је госпођа Давил стигла, настала су у великој и запуштеној згради Француског конзулата нова времена. (ТХ, 66)

2.4. Доба године, а следствено томе и временске прилике, јављају се као својеврстан узрочник догађаја. Стога су у оба романа веома честе конструкције које укључују назив годишњег доба или назив месеца, често са детерминатором, са значењем темпоралне локализације:

Али са јесени поче да одлази војска. (НДЋ, 162); Једне јесени, има од тада око четрнаест година, наишао у хан неки странац. (НДТ, 175); Jow те исте јесени Букус је, иако млад и зелен, постао скитница и коцкар од заната и напустио родитељску кућу. (НДЋ, 185); Већ од половине лета Давна је почео да прибавља податке... (ТХ, 107); Једно време, почетком лета, јахала је по два-три пута у недељи до Орашја, одјахивала са пратњом код цркве, дозивала капелана и давала му упутства како да уреди цркву и кућу. (ТХ, 221); За летних месеии сакупиле би се по три-четири девојке које су везле или плеле. (ТХ, 224); Усред зиме, која је те године била блага и трајала кратко, ти су гласови добили први изглед стварности. (ТХ, 22); Средином лета стигао је нарочити изасланик, султанов капиџибаша, са пратњом. (ТХ, 54); Поткрај лета пронесе се глас да аустријски конзул долази. (...) Али са последюим јесеюим данима стигао је и он. (ТХ, 107); У студено јесене предвече Дефосе би се враћао са својих шетња, мокар, румен и прозебао, пун утисака и потребе да о њима говори. (ТХ, 89); У пролеће оне године кад је пала везирова одлука о градњи, стигли су у касабу његови људи са пратњом да припреме све што треба за грађење моста. (НДЋ, 28). 
Оваква „чиста” локализација, међутим, често има примесе временске адекватности која предодређује успех или пропаст одређеног подухвата или понашање појединца које може имати и кобне последице. Употреба оваквих конструкција у складу је са Андрићевим виђењем „дубљег закона природе”, „са којим се човек судбински среће тамо где га не очекује и кад већ мисли да је већи господар него што јесте” (Кољевић 1982: 38). Стрмом, негостољубивом пејзажу као мизансцену на којем се и живот и мост појављују као светлост и питомост (Кољевић 1982: 34-36), придружују се и временске прилике. Удружени у „дубљи закон природе”, они чине наглашену препреку која је човеку често несавладива. Тако за Грегора Федуна смена зиме и пролећа има кобне последице. Подробно описујући ефекте које на младића имају временске прилике, Андрић им даје статус релевантног елемента у причи о Федуну:

Целе те зиме, која није била ни лака ни кратка, стража од двојице штрајфкора чувала је капију. [...] Међу штрајфкорима који су се смењивали на капији био је један млад човек, Рус из источне Галиције, по имену Грегор Федун. [...] Ту је провео зиму, често сатима тапкајући и хучући у прсте на капији, за мразних, ведрих ноћи кад камен пуца од студени и кад небо убледи над касабом и од крупних јесењих звезда постану ситне и зле свећице. Ту је дочекао и пролеће [...] Младић је стражио, кад је долазила његова реда, осећајући како пролеће, које се јавља кроз земљу и воду, улази полагано у њега, плави му и збуњује сва чула, заноси и мрси мисли. [...] Није лако усредсредити пажњу само на један предмет кад су човеку двадесет три године, кад му телом иду мравци од снаге и живота и кад око њега са свих страна шуми, блешти, мирише пролеће. (НДЋ, 189-191)

Слично се понавља са „младим конзулом” и Јелком јер је интензификација ьеговог доживљаја девојке као 
вегеталне наступила у време „кад је пролеће поодмакло и башта олистала”, а девојке се преместиле у башту: „Како је у то доба све клијало и листало, њему је и она изгледала као део - одуховљени и издвојени део - тога богатог вегеталног света" (ТX, 225). На тај начин и овај мотив улази у ред Андрићевих „варијација на тему”, „варирања већ једном испричаних прича” понављањем карактеристичних момената (в. Кољевић 1982: 63-65).

Честе су јасне и експлицитне назнаке адекватности предузетих подухвата или условљености тока догађања природом годишњих доба. Андрић доследно прати ове цикличне временске смене и даје им статус узрочника догађаја, промене темпа и динамике живота. Временске прилике и годишња доба регулишу живот на микро и макро плану, од вишеградске касабе па до великих царских подухвата. Јесен је доба у којем се све смирује и добија лаганији ритам, што доводи до тога да се је све „блаже и спорије”, „лакше и сношљивије” на свим нивоима - од појединаца до царства:

Укратко, у кући као и у пословима све је са првим данима јесени постало мирније и пријатније. Давила није напуштало неодређено али стално осећање да се све сређује и окреће набоље или бар изгледа лакше и сношљивије. (ТХ, 68).

И иначе догађаји почеше да се смирују и бивају ређи. Наилазила је јесен. Прво рана јесен, са свадбама, бербама, са живљом трговином и бољим приходима, а затим касна, са кишама, кашљем и бригама. Планине су постајале непроходне и људи теже покретни и мање предузимљиви. Свак се спрема да презими ту где се затекао и рачуна како ће претурити зиму. Чак и велика машинерија француског Царства, чинило се Давилу, ради блаже и спорије. (TX, 65).

У овом смислу посебно је илустративан и разговор између везира и француског конзула, где везир изражава сумњу у Наполеонов подухват: 
- Али зашто ваш цар иде сада, пред зиму, на север? То је опасно. Опасно.

[...] И тек после дужег ћутања везир проговори поново, али сада о другој ствари. Причао је како је некада Гисари Челеби-хан кренуо на Русију, разбио у неколико махова противничку војску која се непрестано повлачила, све дубље и дубље, на север. Тада је победничког хана изненадила зима. (TX, 452)

Временске прилике и годишња доба појављују се и као својеврсно и неумитно разрешење сукоба, дилема и драма, како на колективном, тако и на индивидуалном плану. На више места у оба романа Андрић ће нагласити овакву улогу временских прилика као силе којој се човек мора повиновати, као при градњи моста:

Ово је трећа јесен како народ кулучи на мосту [...] Јесен је већ увелико: опало лишће, пропиштали путеви од кише, Дрина надошла и мутна, а гола стрњишта пуна тромих врана. Али Абидага не обуставља радове. (НДЋ, 33-34)

Са наступањем оштре зиме чак ни Абидагина окрутност није довољна да би се радови наставили: посао престаје „сам од себе”. Страх од Абидаге постепено ишчезава и он се, на крају, не враћа у Травник. Сурова зима је, дакле, и временски интермецо који омогућава да се ток догађаја промени и да ново годишње доба отпочне са новим повереником, „посве другачијим човеком”:

А кад је грануло пролеће, није стигао Абидага, него је допутовао нов везиров повереник [...] Са Абидагом се десило оно чега се он толико бојао. Неко, неко ко је добро знао и све изблиза видео, доставио је великом везиру тачне и исцрпне податке о његовом пословању на вишеградском мосту. (НДЋ, 67) 
Природне појаве које су део цикличног времена јесу сила која доводи до последица које људи не могу да спрече, као и у љубавној епизоди између Дефосеа и госпође Фон Митерер. Временске прилике овде су „додајно дејство”, околност која, слично узроку типа повода, „потпомаже да, због већ присутних узрока, у датом моменту дође до реализације посљедице, која би се (будући припремљена другим узроцима) и без њега, повода, десила, али не у том тренутку (Ковачевић 2012: 53-54):

Суви и сунчани дани, кад се и поред студени може јахати, дошли су неминовношћу природних појава. Са истом неминовношћу, према оном божићном договору, искрсли су на смрзнутом путу који води преко Купила јахачи из оба конзулата. [...] Тако је прошао јануар месец, а у фебруару су дошли опет влажни и магловити дани са дубоким блатом и клизавицом, који су спречили оно што ни Давил ни фон Митерер нису смели ни умели да спрече. Јахање је било немогућно. [...] Тај необично топли крај марта месеца убрзао је ток ствари и донео кризу. [...] Тако су се заувек растали ти зимски јахачи, бивши нежни љубавници са Купила. (TX, 302-313)

\section{3. Закључак}

Можемо закључити да је фреквенција одређених адвербатива (или типова адвербатива) са значењем темпоралне локализације у Андрићевим романима Травничка хроника и На Дрини Ћуприја објашњива, између осталог, и тиме што им он придодаје контекстуално условљена нетемпорална значења каузалности. Издвојени модели најчешће осложњавају временско значење узрочним на плану смисла, што се испољава као недовољни узрок, онај који само омогућује или додатно поспешује 
остварење последице. Ови адвербативи не потпадају под типове граматичке интерференције времена и узрока, али потврђују да „разлика између 'довољног' узрока (оног који нужно доводи до последице) и 'недовољног' (који то чини у одређеном проценту, предвидиво или не, или помогнут неким додатним узроком) само донекле одговара инвентару језичких средстава за изражавање узрочних значења" (Чутура 2013: 43).

У раду су издвојена три типа временских одредби које показују могућност овакве интерференције временско-узрочног значења. Први чине изрази типа (c) временом/годинама, који пре свега имају функцију „прескакања” дужих временских периода у наративном ткиву али, додатно, времену дају статус узрочника или омогућивача физичких промена, промена ставова и навика. Други тип односи се на друштвено-историјски одређене периоде, означене именицом време (често у плуралу), као прикривене или непосредне узрочнике чији ефекти постају видни у најразличитијим сферама - од великих политичких и војних збивања па до живота појединаца. Трећи тип чине одредбе са значењем временске локализације у којима је носилац категоријалне семантике именица са значењем доба године или месеца у години. Овај тип посебно је фреквентан у анализираним романима и неретко временским приликама даје статус узрочника или „подстрекача”.

\section{Извори}

Na Drini ćuprija, Sabrana djela Ive Andrića, Sarajevo - Zagreb: Svjetlost - Mladost, 1976.

Travnička hronika, Sabrana djela Ive Andrića, Sarajevo - Zagreb: Svjetlost - Mladost, 1976.

Anikina vremena, u: Jelena, žena koje nema, Sabrana djela Ive Andrića, Sarajevo - Zagreb: Svjetlost - Mladost, 1976. 


\section{Литература}

Брајовић 2011: T. Brajović, Fikcija i moć, ogledi o subverzivnoj imaginaciji Ive Andrića, Beograd: Arhipelag.

Делић 2011: Ј. Делић, Иво Андрић, мост и жртва, Београд: Православна реч - Музеј Града Београда.

Ивић 2005: М. Ивић, Значена српскохрватског инструментала и ғьихов развој, Београд: Београдска књига - Српска академија наука и уметности.

Ковачевић 2003: М. Ковачевић, Пропорционалне у систему поредбених конструкција са значењем једнакости, у: М. Ковачевић, Граматичке и стилистичке теме, Бања Лука: Књижевна задруга, 97-140.

Ковачевић 2012²: М. Ковачевић, Узрочно семантичко поље, Београд: Јасен.

Кољевић 1982: N. Koljević, Na Drini ćuprija Ive Andrića, Beograd: Zavod za udžbenike i nastavna sredstva.

Лешић 2010: 3. Лешић, Теорија книжевности, Београд: Службени гласник.

Марковић 2013: Н. Марковић, Прича о судару Истока и Запада (имаголошки аспекти Травничке хронике Иве Андрића, Узданииа Х/2, 125-140.

Милошевић 1976: Н. Милошевић: На Дрини ћуприја, Андрић и Крлежа као антиподи, Београд: Слово љубве.

Первић 1962: М. Первић, Приповетке Ива Андрића, у: Петар Џаџић (прир.), Критичари о Андрићу, Београд: НОЛИТ, 207-228.

Питулић 2012: В. Питулић, Фолклорни подтекст у „Аникиним временима" Ива Андрића, Научни састанак слависта у Вукове дане 41/2, Иво Андрић у српској и европској књижевности, 257-264.

Принс 2011: Dž. Prins, Naratološki rečnik, Beograd: Službeni glasnik. Свонсон 2012: E. Swanson, The Language of Causation, The Routledge Companion to the Philosophy of Language, London: Routledge, 716-728.

Чутура, Јовановић 2008: И. Чутура, В. Јовановић, Два модела исказивања времена у романима И. Андрића и Б. Ћопића, у: М. Ковачевић (ур.) Сто двадесет пет година високог образовань у 
Босни и Хериеговини, зборник радова, књ. 2, том 1, Пале: Универзитет у Источном Сарајеву, Филозофски факултет, 123-142.

Чутура 2013: И. Чутура, О једном периферном фрагменту узрочног семантичког поља, Узданица X/1, 41-60.

Ilijana R. Čutura

\section{INTERFERENCE OF TIME AND CAUSE IN ANDRIĆ'S NOVELS}

The paper deals with the analysis of different types of temporal adverbials which can be understood as carriers of temporal-causal interference in two novels by Ivo Andrić. Selected novels Na Drini ćuprija and Travnička hronika are characterized by a prominent role of the time in their composition and narration, but also in the thematic and motif layer. Therefore, the paper gives an overview of particularily frequent temporal adverbials, their key roles in both texts and their implicit causal semantic elements.

There are three dominant semantic types of such adverbials. The first one is a group of adverbials which denote time progression and contribute to speciffic narrative compression, which allows the narrator to skip long periods and continue the story at the next 'interesting point.' However, this model includes passive causality (in an implicit and contextually-conditioned way) because it also denotes that the changes improve as the time goes by. The main semantic feature of the second type is that the time is seen as a sociallly and historically determined period which inevitably leads to the changes and consequences at all levels, from nations and communities to individuals. The third type of adverbials are constructions which contain the nouns reffering to a season or a month. This type is primarily a model of temporal localization, but Andrić often emphasizes the role of the weather as additional, passive cause which provokes or accelerates the consequence.

Key words: time, temporal localization, story time, cause, passive cause. 